Ann. Biol. anim. Bioch. Biophys., 1978, 18 (5), 1237-1246.

\title{
Comparative study of extra and intrafollicular hamster oocyte maturation
}

\author{
par Michelle PLACHOT, Jacqueline MANDELBAUM* \\ Laboratoire de cytogénétique humaine et comparée \\ ER 149 CNRS ef U. 173 INSERM. \\ Hôpital des Enfants-Malades, 149, rue de Sèvres, 75730 Paris Cedex 15. \\ Service d'Endocrinologie et de Gynécologie médicale \\ Hôpital Necker, 149, rue de Sèvres 75730 Paris Cedex 15.
}

\begin{abstract}
Summary. A comparative study of intra- and extra-follicular maturation of hamster oocytes checked by in vitro fertilization showed that zona pellucida of extrafollicularly matured oocytes was not penetrated by spermatozoa. Even when gonadotropins (FSH, LH) or ovarian steroids (estradiol and progesterone) were added to the maturation medium they did not render the oocytes fertilizable. Fertilizability was only acquired in vivo 6 to $8 \mathrm{hrs}$ after gonadotropinsurge. Complete intrafollicular hamster oocyte maturation has been obtained in vifro in Ham medium and under 56 p. $100 \mathrm{O}_{2}, 39$ p. $100 \mathrm{~N}_{2}, 5$ p. $100 \mathrm{CO}_{2}$. Gonadotropins were absolutely necessary to complete meiosis up to metaphase II stage. With an optimal dose of $10 \mu \mathrm{g}$ of $\mathrm{FSH}$ and $\mathrm{LH} / \mathrm{ml}, 70$ p. 100 of these oocytes reached metaphase II ; in 43 p. 100 of them, fertilization proceeded normally. We advance the hypothesis that zona maturation is necessary for oocyte penetration and fertilization.
\end{abstract}

\section{Introduction.}

The aptitude of the extrafollicular mammalian oocyte to resume meiosis spontaneously when cultured offers many possibilities for in vitro studies on fertilization and on their further development.

However, with the exception of the mouse (Mukherjee, 1972), all attempts to obtain litters from such in vitro-matured oocytes have been unsuccessful (rabbit : Thibault and Gérard, 1973 ; cow : Hunter et al., 1972 ; sheep : Moor and Trounson, 1977). Histological studies revealed that decondensation of sperm chromatin does not occur or takes place more slowly than in ovulated oocytes. This asynchronism in male and female pronucleus formation may explain abnormal development (rabbit : Thibault and Gérard, 1970 ; Motlik and Fulka, 1974a ; pig : Motlik and Fulka, 1974b ; cow : Thibault ef al., 1975 ; hasmter : Usui and Yanagimachi, 1976). Furthermore, the comparison of protein synthesis during intrafollicular or extrafollicular maturation of sheep oocyte reveals the maintenance of protein pattern synthesis in extrafollicular oocytes as opposed to the switch occurring during normal intrafollicular maturation (Warnes et al., 1977). 
The birth of young (rabbit : Thibault et al., 1975 ; sheep : Moor and Trounson, 1977 ) has shown that it is possible to obtain complete oocyte maturation in vitro when large antral follicles are cultured in presence of gonadotropins.

The ability of hamster sperm to be capacitated in vitro and to fertilize ovulated oocytes (Barros and Austin, 1967), and the obtention of regular nuclear maturation of extrafollicular hamster oocytes in a purely synthetic medium (Haidri and Gwatkin, 1973) encouraged us to reinvestigate the different aspects of oocyte maturation in this species (Mandelbaum and Plachot, 1977 ; Mandelbaum et al., 1977).

\section{Material and methods.}

Follicle and oocyte recovery. - Oocytes from preovulatory follicles encompassed in the cumulus cells, or entire preovulatory follicles, have been collected from cyclic female hamsters $48 \mathrm{hrs}$ after the injection of $30 \mathrm{IU}$ of PMSG given in the morning of estrus.

Control tubal oocytes were obtained from females receiving a $30 \mathrm{IU}$ HCG injection 48 hrs after PMSG pretreatment. Oocytes were collected in the tubes 16 hrs later.

Culture system for maturation and fertilization.

- Extrafollicular oocytes were cultured in $0.5 \mathrm{ml}$ of $\mathrm{GH}_{2}$ medium (Haidri and Gwatkin, 1973) under paraffin oil and a gas mixture containing air ( 95 p. 100) and $\mathrm{CO}_{2}(5 \mathrm{p} .100)$ for $12 \mathrm{hrs}$ at $37^{\circ} \mathrm{C}$. Fertilization of these oocytes was attempted in $0.5 \mathrm{ml}$ of $\mathrm{GH}_{2}$ medium with the same gas mixture.

- Intrafollicular oocyles were cultured in Falcon dishes in $0.5 \mathrm{ml}$ of either Ham F 10 medium or TC 199 medium supplemented or not with fotal calf serum (15 p. 100), hamster serum (15 p. 100) and chicken embryo extract (20 p. 100).

1 to $20 \mu \mathrm{g} / \mathrm{ml}$ of ovine FSH and LH or estradiol $17 \beta(0.1 \mu \mathrm{g} / \mathrm{ml})$ and progesterone $(1 \mu \mathrm{g} / \mathrm{ml})$ were added to the preceding maturation media. Two culture systems were used to avoid granulosa pyknosis :

- in some experiments the increase of oxygen tension was obtained under a pressure of 5 bars, in an atmosphere containing air (95 p. 100) and $\mathrm{CO}_{2}$ (5 p. 100) according to Thibault and Gérard's method (1973) ;

- other experiments were performed under a gas mixture containing $\mathrm{O}_{2}$ (56 p. 100), $\mathrm{N}_{2}$ (39 p. 100) and $\mathrm{CO}_{2}$ (5 p. 100).

Cultures were limited to $16 \mathrm{hrs}$ at $37^{\circ} \mathrm{C}$. The fertilization attempts of these intrafollicularly matured oocytes were realized in $\mathrm{Ham} F 10$ or $\mathrm{GH}_{2}$ medium under air (95 p. 100) and $\mathrm{CO}_{2}$ (5 p. 100).

Method of ferfilization.

1. In each fertilization attempt, the caudal epididymal sperm samples were recovered according to Wittingham and Bavister (1974); the same sample of epididymal sperm was used for the fertilization of in vivo or in vitro matured oocytes.

2. Tubal or follicular fluid was added to the fertilization medium as shown by Barros (1968) to improve the fertilization rate. 
a) fubal fluid was collected by flushing a tube of a preovulatory female hamster with $0.5 \mathrm{ml}$ of medium. This medium containing tubal fluid represented the fertilizafion medium ;

b) follicular fluid was obtained by opening 10 preovulatory follicles before the LH discharge in $0.5 \mathrm{ml}$ of medium. The follicular walls and the oocytes were removed but the granulosa and cumulus cells were left.

3. The following criteria for egg fertilization were utilized:

- presence of the second polar body ;

- presence of two pronuclei in the oocyte cytoplasm.

We were not able to recognize the sperm tail with its midpiece which soon disappears after fertilization.

Eggs were fixed either according to Tarkowski's method (1966) or in Bouin medium and then cut after a double embedding in gelatin paraffin and stained with hematoxylin-eosin.

\section{Results.}

1. Fertilization rate of freshly ovulated oocytes. - Oocytes examined $24 \mathrm{hrs}$ after sperm and oocyte mixing are in pronuclear stage.

When tubal or follicular fluid is added to the fertilization medium, respectively 50 p. $100(7 / 14)$ and 80 p. $100(60 / 77)$ of the oocytes are fertilized.

As the highest fertilization rate was obtained with follicular fluid ( $P<0,02$ with $\chi^{2}$ test), this medium was therefore used for all fertilization experiments.

2. Attempts to fertilize extrafollicularly matured oocyfes. - When extrafollicularly cultured oocytes are examined 12 to 16 hrs later, 90 p. $100(92 / 102)$ have reached metaphsae II stage, but these oocytes are not fertilizable. Cytological examination of hematoxylin-eosin stained serial sections of eggs, show that sperm heads, although in contact with the zona pellucida, never penetrate it.

\section{TABLE 1}

In vitro fertilization of extrafollicularly matured oocytes

\begin{tabular}{|c|c|c|c|}
\hline Mafuration medium & Fertilization medium & $N^{o}$ of oocytes & $\begin{array}{l}\text { Fertilization } \\
\text { p. } 100\end{array}$ \\
\hline $\mathrm{GH}_{2} \ldots \ldots \ldots \ldots \ldots \ldots \ldots \ldots \ldots$ & $\mathrm{GH}_{2}+$ tubal fluid & 3 & 0 \\
\hline $\mathrm{GH}_{2} \ldots \ldots \ldots \ldots \ldots \ldots \ldots \ldots \ldots \ldots \ldots$ & $\mathrm{GH}_{2}+$ follicul. fluid & 37 & 0 \\
\hline $\begin{array}{l}\mathrm{GH}_{2} \ldots \ldots \ldots \ldots \ldots \ldots \ldots \ldots \ldots \ldots \ldots \ldots \ldots \ldots \\
\quad+\mathrm{FSH}(10 \mu \mathrm{g} / \mathrm{ml}) \\
\quad+\mathrm{LH}(10 \mu \mathrm{g} / \mathrm{ml})\end{array}$ & $\mathrm{GH}_{2}+$ follicul. fluid & 11 & 0 \\
\hline $\begin{array}{l}\mathrm{GH}_{2} \ldots \ldots \ldots \ldots \ldots \ldots \ldots \\
\quad+\text { estradiol }(0,1 \mu \mathrm{g} / \mathrm{ml}) \\
\quad+\text { progesterone }(1 \mu \mathrm{g} / \mathrm{ml})\end{array}$ & $\mathrm{GH}_{2}+$ follicul. fluid & 21 & 0 \\
\hline
\end{tabular}


As FSH and perhaps LH show a specific dispersive action on the cumulus cells which elongate at the same time. (Thibault, 1972 ; Thibault et al., 1975) and as cumulus cells have been implicated in the capacitation process, (Gwatkin ef al., 1972), we added gonadotropins to the maturation medium. No sperm penetration occurred although cumulus cells were dissociated.

The dissociation of the cumulus cells is called positive $(+)$ when it appears identical to the dispersive aspect of the cumulus surrounding the tubal oocytes recovered early after ovulation.

Fertilization also failed when estrogen and progesterone were added without gonadotropins (table 1).

Thus, zona pellucida penetrability does not seem to depend on the stimulation of cumulus cells either by gonadotropins or follicular steroids.

3. When does the zona pellucida become penetrable in vivo? Oocytes are collected at increasing time intervals after HCG injection and further cultured for 2 to $10 \mathrm{hrs}$ so that all the oocytes have matured for $12 \mathrm{hrs}$ before attempted insemination trials. Sperm penetration as shown in table 2, appears when oocytes remain at least 6 hrs in the follicle after HCG injection; sperm nucleus decondensation always occurs.

\section{TABLE 2}

In vitro fertilization after combined in vivo and in vitro oocyte maturation

\begin{tabular}{|c|c|c|c|c|}
\hline $\begin{array}{l}\text { Time of oocyte } \\
\text { recovery after } \\
\text { HCG injection } \\
\text { (in hrs) }\end{array}$ & $\begin{array}{l}\text { Additional } \\
\text { culture time } \\
\text { (in hrs) } \\
\text { in } \mathrm{GH}_{2} \text { medium }\end{array}$ & $\begin{array}{c}\text { Dissociation } \\
\text { of cumulus cells }\end{array}$ & $N^{0}$ of oocytes & $\begin{array}{l}\text { Fertilized oocytes } \\
\qquad(\mathrm{p} .100) \\
\text { in } \mathrm{GH}_{2} \text { medium } \\
\text { follicular fluid }\end{array}$ \\
\hline $\begin{array}{c}2 \\
4 \\
6 \\
8-10 \\
12\end{array}$ & $\begin{array}{c}10 \\
8 \\
6 \\
4-2 \\
0\end{array}$ & $\begin{array}{l}- \\
+ \\
+ \\
+-\end{array}$ & $\begin{array}{r}26 \\
49 \\
56 \\
8 \\
7\end{array}$ & $\begin{array}{r}0 \\
6 \\
27 \\
50 \\
86\end{array}$ \\
\hline
\end{tabular}

The longer the oocyte remains in the follicle, the greater the fertilization rate.

The follicle thus seems necessary for complete oocyte maturation in vitro, leading to a normal sperm penetration.

4. In vitro fertilization of intrafollicularly matured hamster oocytes. - As in other species (rat : Tsafriri et al., 1972 ; rabbit : Thibault and Gérard, 1973 ; sheep : Moore and Trounson, 1977) nuclear oocyte maturation is only observed when gonadotropins are added to the maturation medium (table 3). The number of matured oocytes increases with the amount of FSH and LH until an optimal dose of $10 \mu \mathrm{g} / \mathrm{ml}$ is reached.

Several culture systems were used combining :

- 3 maturation media containing gonadotropins : Ham F 10 ; Ham F 10 supplemented with fœtal calf serum (15 p. 100), hamster serum (15 p. 100) and chicken embryo extract (20 p. 100), and TC 199 supplemented in the same way; 
- 2 oxygenation systems : air $-\mathrm{CO}_{2}$ under 5 bars or gas containing 56 p. $100 \mathrm{O}_{2}$, 39 p. $100 \mathrm{~N}_{2}$ and 5 p. $100 \mathrm{CO}_{2}$ under atmospheric pressure.

\section{TABLE 3}

Influence of FSH and $\mathrm{LH}$ on maturation rate of follicular-enclosed oocytes This table represents all the results obtained either in pressure gas or under 56 p. 100 of oxygen.

\begin{tabular}{|c|c|c|}
\hline Media & $\begin{array}{l}\text { FSH and } \dot{L} H^{-} \\
(\mu \mathrm{g} / \mathrm{ml})\end{array}$ & $\begin{array}{l}\text { Oocyte maturation } \\
\text { (Meta. II) p. } 100\end{array}$ \\
\hline Ham & $\begin{array}{r}0 \\
1 \\
5 \\
10\end{array}$ & $\begin{array}{c}13(1 / 8) \\
8(1 / 12) \\
50(9 / 18) \\
50(56 / 115)\end{array}$ \\
\hline $\begin{array}{l}\text { Ham } \\
+ \text { foetal calf serum } 15 \text { p. } 100 \\
+ \text { hamster serum } 15 \text { p. } 100 \\
+ \text { chicken embryo extract } 20 \text { p. } 100\end{array}$ & $\begin{array}{r}0 \\
1 \\
5 \\
10\end{array}$ & $\begin{array}{l}0(0 / 8) \\
17(2 / 12) \\
12(1 / 9) \\
30(2 / 7)\end{array}$ \\
\hline$\left\{\begin{array}{l}199 \\
+ \text { fotal calf serum } 15 \text { p. } 100 \\
\text { t- hamster serum } 15 \text { p. } 100 \\
+ \text { chicken embryo extract } 20 \text { p. } 100\end{array}\right.$ & $\begin{array}{r}5 \\
10 \\
20\end{array}$ & $\begin{array}{l}22(2 / 9) \\
44(14 / 32) \\
41(7 / 17)\end{array}$ \\
\hline
\end{tabular}

The best in vitro maturation rate is obtained with Ham medium containing $10 \mu \mathrm{g} /$ $\mathrm{ml}$ of $\mathrm{FSH}$ and $\mathrm{LH}$ under a gas mixture containing 56 p. 100 of $\mathrm{O}_{2}$. After $16 \mathrm{hrs}$ of culture, 70 p. $100(27 / 40)$ of the oocytes are in metaphase II stage. The other culture systems show maturation rate from 30 to 47 p. 100 . At the end of the maturation, oocytes are removed from the follicle, transferred in fertilization medium and then inseminated. 36 p. 100 to 62 p. 100 of these in vitro intrafollicularly matured oocytes are penefrated and fertilized. They reach pronuclear or 2-cell stages 16 to $24 \mathrm{hrs}$ later (table 4).

\section{TABLE 4}

In vitro fertilization of intrafolliculary matured oocytes

\begin{tabular}{|c|c|c|}
\hline Maturation medium & $\begin{array}{c}\text { Fertilization medium } \\
\text { under air }(95 \mathrm{p} .100) \\
\text { and } \mathrm{CO}_{2}(5 \mathrm{p} .100)\end{array}$ & Fertilization p. 100 \\
\hline $\begin{array}{l}\text { Ham } \\
\qquad t^{-} \mathrm{FSH}(10 \mu \mathrm{g} / \mathrm{ml})\end{array}$ & Ham + follicular fluid & $36(8 / 22)$ \\
\hline $\begin{array}{l}+\mathrm{LH}(10 \mu \mathrm{g} / \mathrm{ml}) \\
\text { under } 56 \text { p. } 100 \text { of oxygen }\end{array}$ & $\mathrm{GH}_{2}+$ follicular fluid & $62(5 / 8)$ \\
\hline
\end{tabular}





\section{PLATE I}

FIG. 1. - In vifro extrafollicularly matured hamster oocyłe. Metaphase II stage. Hematoxylin-eosin.

FIG. 2. - Extrafollicularly matured hamster oocyfe unpenetrated by hamster sperm head in vitro. $20 \mathrm{hrs}$ after the beginning of the fertilization attempt (phase contrast).

FIG. 3. - In vitro intrafollicularly matured hamster oocyte. Formation of the first polar body (anaphase I). Hematoxylin-eosin.

FIG. 4. - In vitro fertilization of intrafollicularly matured hamster oocyfe. Note the polar bodies and two pronuclei in the cytoplasm. Hematoxylin-eosin. 


\section{Discussion.}

Extrafollicularly matured hamster oocytes could not be fertilized because the spermatozoa never passed through the zona pellucida as shown by cytological examination. This has never been described in other mammalian oocytes. In the hamster, a fertilization block occurs at the zona level since Usui and Yanagimachi (1976) only obtained in vitro fertilization of oocytes at different stages of their nuclear maturation by using zona-free oocytes.

It is hardly credible that capacitation should be concerned, as 80 p. 100 of freshly ovulated oocytes are fertilized in vitro in the well defined and repeatable conditions of our experiments, except if the final steps of capacitation occurring during the contact between acrosome and zona pellucida are absent. We need ultrastructural studies to obtain a detailed picture of sperm head-zona pellucida connections. If capacitation is not concerned, there may be a blockade at the zona pellucida level.

Two propositions may explain this phenomenon :

1) Complete cortical reaction occurs in extrafollicularly matured oocytes before sperm penetration. However, it seems that only the fertilizing spermatozoon is able to induce a complete cortical reaction and that parthenogenetic activation of oocytes in different species by various stimuli leads to incomplete cortical reaction. Longo (1977) also observes an incomplete cortical reaction by spontaneous activation of unfertilized hamster eggs after a prolonged stay in the oviduct. Culture conditions ( $\mathrm{pH}$, temperature, osmolarity) may have activated oocytes with an incomplete cortical reaction sufficient to block the sperm entry. This would not appear in follicle-enclosed oocytes matured in vitro. Ultrastructural studies are in progress to verify this hypothesis.

2) The maturation of the zona pellucida may play a role ; the nature of this maturation is unknown but it would be a necessary prerequisite for sperm penetration.

We propose that there is a change in the nature or in the configuration of zona proteins, a sort of mirror image of the change occurring after cortical granule discharge, which renders the zona insensitive to acrosome enzymes. So, hasmter oocyte maturation includes at leasi three stages: a nuclear maturation leading to metaphase II, a maturation involving zona pellucida that we call «zona maturation ", and a cytoplasmic maturation leading to fast sperm nucleus swelling (Usui and Yanagimachi, 1976). Cytoplasmic and zona maturation proceed in vivo in the preovulatory follicle approximately $6 \mathrm{hrs}$ after gonadotropin surge. Tubal fluid does not play any role in this process as 86 p. 100 of ovarian oocytes collected $12 \mathrm{hrs}$ after HCG injection are ferfilized. The zona maturation is achieved in the follicle 6 to 8 hrs after HCG injection ; 56 p. 100 of the oocytes collected at this fime from the ovary and finishing their maturation in vitro are fertilized. We observe no abnormal male pronucleus growth as Usui and Yanagimachi did, but we only studied the end phase of fertilization as proved by the presence of the second polar body and two pronuclei in the oocyte cytoplasm. Examination of the early stages after sperm penetration would be necessary to be sure that cytoplasmic maturation is really achieved concomitantly with zona maturation. However, when oocytes can be penetrated, their fertilization also seems to be normal. 
Zona maturation in the hamster does not depend on the direct action of gonadotropins on the oocyte or on the cells surrounding it. When FSH and $\mathrm{LH}$ were added to the maturation medium of extrafollicularly matured oocytes, sperm penetration was not observed although the specific dispersive action of the gonadotropins on cumulus cells, already observed in vitro by Thibault (1972), was still present.

As gonadotropins also enhance steroidogenesis by follicular cells it is probable that high steroid levels were responsable for zona and cytoplasmic maturation, and that extrafollicular oocytes could not reproduce this hormonal event even when surrounded by cumulus cells.

Our attempts to mature zona by $17 \beta$ estradiol and progesterone were unsuccessful. However, we have not duplicated the steroid sequence found in plasma (estradiol peak followed by an increase of progesterone) and probably have not reached the follicular steroid levels. It would be necessary to know the intrafollicular hormonal sequence in detail to reproduce the true physiological condition in vitro.

We cultured PMSG-induced preovulatory hamster follicles. It is interesting to note that nutritional requirements for maturation of extra and intrafollicular oocytes are different. The $\mathrm{GH}_{2}$ medium described by Haidri and Gwatkin (1973) is the optimal medium for extrafollicular oocyte maturation but does not allow the maturation of follicle-enclosed oocytes. The intrafollicular oocytes probably need more amino acid and nucleic acid precursors as contained in Ham medium (and not in $\mathrm{GH}_{2}$ ) during in vitro maturation.

As in other mammals (rat : Lindner ef al., 1974 ; calf : Thibault ef al., 1975 ; rabbit : Thibault and Gérard, 1973 ; macaque : Thibault et al., 1976 ; sheep : Moor and Trounson, 1977) gonadotropins (FSH, LH) are absolutely necessary to reinitiate meiosis, when follicles are cultured in toto.

Recently, Gwatkin and Andersen (1976) made the same observation in hamster. The number of oocytes in metaphase II increases with the gonadotropin level until an optimal dose of $10 \mu \mathrm{g} / \mathrm{ml}$ is reached. This dose is usually employed in other mammals, except the sheep where Moor and Trounson have shown that more than $2 \mu \mathrm{g} / \mathrm{ml}$ of FSH and $1 \mu \mathrm{g} / \mathrm{ml}$ of LH depressed blastocyst formation while it significantly increased the fragmentation rate. Intrafollicularly cultured oocytes mature complefely since 43 p. 100 of them are fertilized normally, as was also observed by Thibault ef al. (1975) in the rabbit and Moor and Trounson (1977) in the sheep.

Reçu en mai 1978. Accepté en juin 1978.

Acknowledgements. - We gratefully thank Pr. C. Thibault for his constant assistance and encouragement during this study and Pr. Jutisz for the generous donation of ovine gonadotropins.

Résumé. Les tentatives de fécondation in vitro d'ovocytes de Hamster ayant achevé leur maturation soit hors du follicule, soit à l'intérieur du follicule, montrent que les spermatozoïdes ne pénètrent pas la membrane pellucide des ovocytes maturés hors du follicule. $\mathrm{Ni}$ FSH ou LH, ni l'estradiol et la progestérone ajoutés au milieu de culfure pendant la maturation, en rendent la membrane pellucide pénétrable. In vivo, cette propriété n'est acquise que 6 à $8 \mathrm{~h}$ après la décharge ovulante de gonadotropines. La maturité complète 
de l'ovocyte de Hamster a pu être obtenue in vitro dans son follicule cultivé dans du milieu de $\mathrm{Ham}$, sous 57 p. 100 d'O$_{2}, 38$ p. 100 de $\mathrm{N}_{2}$ et 5 p. 100 de $\mathrm{CO}_{2}$. FSH et LH sont absolument indispensables pour obtenir dans de telles conditions la reprise de la méïose jusqu'à la métaphase II. En présence de $10 \mu \mathrm{g}$ de FSH et de LH par millilitre de milieu, 70 p. 100 des ovocytes intrafolliculaires atteignent la métaphase II et 43 p. 100 d'entre eux sont fécondés normalement (pénétration et formation des pronuclei). Il semble donc que normalement l'ovocyte de Hamster subisse peu avant l'ovulation un changement de sa membrane pellucide, qui la rend pénétrable par le spermatozoïde capacité.

\section{References}

BARROS C., 1968. In vitro capacitation of golden hamster spermatozoa with Fallopian tube fluid of the mouse and rat. J. Reprod. Fert., 17, 203-206.

BARROS C., AUSTIN C. R., 1967. In vitro fertilization and the sperm acrosome reaction in the hamster. J. exp. Zool., 166, 317-323.

GWATKIN R. B. L., ANDERSEN O. F., 1969. Capacitation of hamster spermatozoa by bovin follicular fluid. Nature, 224, 1111-1112.

GWATKIN R. B. L., ANDERSEN O. F., 1976. Hamster oocyte maturation in vitro : inhibition by follicular components. Life Sci., 19, 527-536.

GWATKIN R. B. L., ANDERSEN O. F., HUTCHINSON C. F., 1972. Capacitation of hamster spermatozoa in vitro : the role of cumulus components. J. Reprod. Fert., 30, 389-394.

HAIDRI A. A., GWATKIN R. B. L., 1973. Requirements for the maturation of hamster oocytes from preovulatory follicles. J. Reprod. Fert., 35, 173-176.

HUNTER R. H. F., LAWSON R. A. S., ROWSON L. E. A., 1972. Maturation transplantation and fertilization of ovarian oocytes in cattle. J. Reprod. Fert., 30, 325-328.

LINDNER H. R., TSAFRIRI A., LIEBERMAN M. E., ZOR U., KOCH Y., BAUMINGER S., BARNEA A., 1974. Gonadotropin action on cultured graafian follicles : induction of maturation division of the mammalian oocyte and differenciation of the luteal cells. Rec. Progr. Hormone Res., 30, 79-138.

LONGO F. J., 1977. An ultrastructural analysis of spontaneous activation of hamster eggs aged in vivo. Anat. Rec., 179, 27-56.

MANDELBAUM J., PLACHOT M., 1977. Infécondabilité de l'ovocyte de hamster ayant fait sa maturation in vitro. C. R. Acod. Sci. Poris, sér. D, 284, 953-955.

MANDELBAUM J., PLACHOT M., THIBAULT C., 1977. Rôle of the follicle in zona pellucida maturation of hamster oocyte. Ann. Biol. anim. Bioch. Biophys., 17, 389-391.

MOOR R. M., TROUNSON A. O., 1977. Maturation of sheep oocytes in vitro : effects of gonadotropins and steroids on embryonic development. J. Reprod. Fert., 49, 101-109.

MOTLIK J., FULKA J., 1974a. Fertilization and development in vivo of rabbit oocytes cultivated in vitro. J. Reprod. Fert., 40, 183-186.

MOTLIK J., FULKA J., 1974b. Fertilization of pig follicular oocytes culfivated in vitro. J. Reprod. Fert., 36, 235-237.

MUKHERJEE A. B., 1972. Normal progeny form fertilization in vitro of mouse oocytes matured in culture and spermatozoa capacitated in vitro. Nature, 237, 397-398.

TARKOWSKI A. K., 1966. An air-drying method from chromosome preparation form mouse eggs. Cytogenetics, 5, 394-400.

THIBAULT C., 1972. Final stages of mammalian oocyte maturation, 397-411. In Oogenesis, BIGGERS J. D., SCHUETZ A. W. Univ. Press. Baltimore.

THIBAULT C., GERARD M., 1970. Facteur cytoplasmique nécessaire à la formation du pronucleus male dans l'ovocyte de lapine. C. R. Acad. Sci. Paris., sér. D, 270, 2025-2026.

THIBAULT C., GERARD M., 1973. Cytoplasmic and nuclear maturation of rabbit oocytes in vitro. Ann. Biol. onim. Bioch. Biophys., 13, hors série, 145-156.

THIBAULT C., GERARD M., MENEZO Y., 1975. Acquisition par l'ovocyte de lapine et de veau, du facteur de décondensation du noyau du spermatozoide fécondant (MPGF). Ann. Biol. onim. Bioch. Biophys., 15, 705-714. 
THIBAULT C., GERARD M., MENEZO Y., 1976. Nuclear and cytoplasmic aspects of mammalian oocyte maturation in vitro in relation to follicle size and fertilization. In HUBINONT P. $O$. «Sperm action 》. Prog. Reprod. Biol., 1, 233-240, Karger, Basel.

TSAFRIRI A., LINDNER H. R., ZOR U., LAMPRECHT S. A., 1972. In vitro induction of meiotic division in follicle enclosed rat oocytes by LH, cyclic AMP and prostaglandin $E_{2}$ J. Reprod. Fert., 31, 3950.

USUI N., YANAGIMACHI R., 1976. Behavior of hamster sperm nuclei incorporated into eggs at various stages of maturation fertilization and early development. J. Ultrastr. Res., 57, 276-288.

WARNES G. M., MOOR R. M., JOHNSON M. H., 1977. Changes in protein synthesis during maturation of sheep oocytes in vivo and in vitro. J. Reprod. Fert., 49, 331-335.

WHITTINGHAM D. G., BAVISTER B. D., 1974. Development of hamster eggs fertilized in vifro or in vivo. J. Reprod. Ferf., 38, 489-492. 